\title{
The Osona Research Group on Folklore: research and the archive
}

\author{
F. Xavier Roviró i Alemany \\ Osona Research Grup on Folklore \\ xroviro@gmail.com
}

\begin{abstract}
Josep Maria Pujol shared our passion for folklore research. Together we took part in several research projects on oral folklore. We loved talking about how to approach language and transcription, the importance of conversation and, above all, folkloric communication. Josep Maria Pujol was our benchmark and guarantor.

The methodology adopted by the Osona Research Group on Folklore (I980) was the result of a lot of thought that can be summarized in ten points: group work; a theoretical base; the importance of technology; recordings; an understanding of the place; data collection; inventory and classification; conversation as the basis of research; the relationship with the informant; and a careful approach to language.

The results of the research campaigns are a collection of files with more than 700 informants and almost 2I, ooo fragments of conversations on issues of folklore. We have classified these fragments into the following topics: comments on music and songs; ballad songs; the cycle of life and of the year; instrumental; enchanted tales; the Damned; gnomes; witches; apparitions; powers; beings from Heaven or Hell; nature; about places; bandits; children's tales; remedies; prayers; saying and riddles; verses; festivities; games; other customs; contemporary rumours and legends.
\end{abstract}

KEYWORDS

Oral folklore; informant; folk communication; genre; archive 


\section{RESUM}

Amb Josep Maria Pujol ens va unir la passió cap a la recerca folklòrica. Junts férem diversos treballs d'investigació $i$ d'estudi del folklore oral. Ens apassionaven parlant sobre la manera de com tractar la llengua i la transcripció, de la importància de la conversa i, especialment, sobre la comunicació folklòrica. Així en Josep Maria Pujol va ser el nostre punt de referència i el nostre avalador.

La metodologia de treball del Grup de Recerca Folklòrica d'Osona (I980) ha estat el resultat d'abundants i fecundes reflexions que podem sintetitzar en deu punts: treball en grup; base teòrica; importància de la tecnologia; enregistraments; coneixement del lloc; presa de la informació; arxivar; conversa com a base de recerca; relació amb l'informant; tractar la llengua amb molta cura.

Fruit de les campanyes de recerca tenim uns arxius amb més de 7oo informants $i$ gairebé 21 . ooo entrades de fragments de converses d'interès folklòric. Els fragments de les converses mantingudes durant les nostres recerques de folklore oral les hem classificades en els següents temes: comentaris sobre música i cançons; cançons baladístiques; del cicle de l'any i de la vida; instrumental; encantades; condemnats; el follet; bruixes; apareguts; poders; éssers del cel i de l'infern; natura; de llocs; bandolers; contes; remeis; oracions; dites i endevinalles; versos; festes calendàries; jocs; altres costums; rumors $i$ llegendes contemporànies.

PARAules ClaU

Folklore oral; informant; comunicació folklòrica; gènere; arxiu

REBUT: 28/II/2OI6 | ACCEPTAT: OI/I2/2OI6 
AT THE GRup de Recerca FolKLòrica D'Osona (Osona Research Group on Folklore) we first became aware of Josep Maria Pujol thanks to an article in a book published by Altafulla in I985 on popular culture (Pujol I985). Also in that period, Josep Maria became aware of us because of a book of tales that we published in Rupit i Pruit (GRFO I984). Shortly after, we had the chance to get to know each other, after which time we saw a lot of him. We spoke about how to approach research on folklore, language and transcription, and we discussed the importance of conversation and folkloric communication, all of which are subjects that we were extremely passionate about. Not long after the Folkloric Studies Conference of I99I in Vic, in which he took active part, he joined the GRFO team. Then, other projects came along, one of which was a study of contemporary rumours and legends, the results of which were published in 2002 (GRFO/Pujol 2002).

Why did we decide to work together? For several reasons, but especially the methodology that we used in the GRFO to research into orally transmitted popular and traditional culture. We also gave importance to the study and research of oral folklore.

That's how Josep Maria Pujol became our benchmark and guarantor.

Since I980 the GRFO has been constantly, intensely and intensively involved in research, mostly within the boundaries of the Osona region. We needed a frame of reference and we decided to prioritise the fact that we were part of the same community as our informers. Besides, the area was at once manageable and quite large enough for our purposes.

The methodology we used was the result of a great deal of thought and it has several strong points that, from our point of view, make it rather effective. The framework we used can be summed up in ten points:

I. Group work. We based our research on working as a group so that it was a more enriching and challenging experience.

2. A theoretical base. We did not want to wander around aimlessly wasting time and effort, so we furnished our research with a solid theoretical base.

3. The importance of technology. We used the best technology available (Tape, MiniDisk, Dat, $\mathrm{MP}_{3}$ ) to record and archive the folklore.

4. Recordings. We believe that sound recordings must be coupled with images. 
5. Understanding the place. In every campaign we gained greater insight into the places (their geography, toponyms, society, folklore and history) in which we did our research.

6. Data collection. We wanted to ensure that the information we collected was valid: the recordings were of the highest quality possible, we found out as much as possible about every informant, we determined where they had heard each tale, we visited (when possible) where the tale is set, etc.

7. Inventory and classification. It is of the utmost importance to organise all the material and information collected. It must be well classified to be useful.

8. Conversation as the basis of research. We believe that it is more important to have a conversation with informants than to make them fill in a form. This means that most of our conversations were with individuals and not groups.

9. The relationship with the informant. We always prioritised our relationship with the informants and not the information that we received from them.

Io. A careful approach to language. We tried to be as faithful as possible to spoken language. We regard every tale and story as unique and unrepeatable, and we are aware that every tale is part of a conversation which is then cut and extracted according to our own criteria. We transcribed our conversations according to some transcription criteria rather than phonetically. We usually provide a comprehensive summary of each tale.

The most intensive work was structured around research campaigns. ${ }^{\mathrm{I}}$ Thanks to these campaigns we were able to carry out extensive and meticulous research into the oral folklore in Osona and check its status. Almost 700 people from the towns and villages within the region were involved as our informants, and we had long and varied conversations with them.

Every conversation was recorded and catalogued. The recordings are classified in independent summaries of each conversation called phonograms (FONOS). Each phonogram has a number that identifies the name and surname of the informant, and the date and place of the recording. Each phonogram is split into fragments and each fragment has a number for order, classification, degree of interest $(\mathrm{O}=$ not interesting, $\mathrm{I}=$ not very interesting, $2=$ interesting, $3=$ rather interesting, 4= very interesting and 9 for "unrated") and a brief description of its content (usually with some personal insight from the researcher who made the summary).

In total there are about 2I, ooo items, of different order and interest.

\footnotetext{
I. These campaigns took place in the following places: 198I municipality of Rupit i Pruit (Collsacabra); 1982 municipality of Prats and part of El Lluçanès; I983 Perafita and the rest of El Lluçanès; I984 Viladrau and Montseny and Guilleries; 1985 Centelles and Osona Sud (Congost); I986 Torelló and Osona Nord (Vall del Ges, Bisaura, Puigsacalm); I987 part of the Plana de Vic (small municipalities); 1988 the rest of the Plana de Vic (small municipalities); I989 part of the Plana de Vic (large municipalities); I990 rest of the Plana de Vic (large municipalities); I99I rest of Osona.
} 
We created a database so that we could search for every item in each category. Therefore, all the information in the archive can be quickly and easily accessed.

The summaries (also called drafts) were made during the conversations with the informants so we consider them to be direct research products, working documents.

Every informant has a detailed file (age, place of birth, address, family, comments, etc.) that includes a research diary for contextualising a given conversation. When possible we have taken pictures of the informants.

The table below summarises all themes and gives the codes and the number of phonograms for the most important archives of the GRFO:

\begin{tabular}{|c|c|c|}
\hline Code & Theme & $\begin{array}{c}\text { Number of } \\
\text { FONOS }\end{array}$ \\
\hline & TOTAL & 20307 \\
\hline OoO & $\begin{array}{l}\text { Not specified } \\
\text { This is a very interesting chapter because it contains important } \\
\text { and varied information about a conversation. It contains such } \\
\text { things as: } \\
\text { Initial comments, final comments, information about the } \\
\text { informant, theme summary, and anecdotes about work, study, } \\
\text { weather, the war, student life, being young at the time, hunting, } \\
\text { places, etc; comments on jobs, singular characters, smoking, } \\
\text { water and fountains, Verdaguer, family, transportation, radio, } \\
\text { the harvest, the Carlins, the military service, chestnuts, } \\
\text { mushrooms, the market, the forest. Mural recommendations } \\
\text { and many moments worth remembering. }\end{array}$ & 5672 \\
\hline IOO & Comments on music and songs & 8 \\
\hline IIO & $\begin{array}{l}\text { Ballad songs } \\
\text { Of the } 243 \text { I ballad songs, almost half (II42) are catalogued as } \\
\text { interesting (rated 3) or very interesting (rated 4). There are many } \\
\text { versions of songs such as: Els segadors, Els tres tambors, La dama } \\
\text { d'Aragó, El cornut, El pardal, La dida, El caçador, Els estudiants de } \\
\text { Tolosa or La cançó d'en Serrallonga. }\end{array}$ & $243 \mathrm{I}$ \\
\hline $\mathrm{I} 2 \mathrm{O}$ & $\begin{array}{l}\text { The cycle of life and of the year. } \\
\text { Of the } 2053 \text { entries, } 645 \text { are rated as a } 3 \text { or a } 4 \text {. In this group } \\
\text { we can find many children's songs: Fum, fum, fum; Arri, arri } \\
\text { burriquet, Ara plou, ara neva, Pico, plano. Christmas carols and } \\
\text { other festivities: Corrandes, Record i memòria, Els Reis de l'Orient, } \\
\text { Sant Josep fa de fuster, Els goigs del Roser. Or other songs such as: } \\
\text { El ball de la civada, La sardana carlina de Rupit. }\end{array}$ & 2053 \\
\hline I3O & $\begin{array}{l}\text { Instrumental } \\
\text { Most entries are pieces played with a small flute and bass drum. } \\
\text { Comments on dances, instruments and the performer can also } \\
\text { be found here. }\end{array}$ & $4 \mathrm{IO}$ \\
\hline
\end{tabular}




\begin{tabular}{|c|c|c|}
\hline Code & Theme & $\begin{array}{c}\text { Number of } \\
\text { FONOS }\end{array}$ \\
\hline $2 \mathrm{IO}$ & $\begin{array}{l}\text { Encantades (enchanted tales) } \\
\text { The "encantats" or "encantades" (which can be loosely } \\
\text { translated as "enchanted tales") are one of the most interesting } \\
\text { narrative themes in the oral tradition. Unfortunately, today } \\
\text { they are extinct in the folklore of Osona and Catalonia in } \\
\text { general. A great many people gave us minor details about these } \\
\text { tales (clothing, singing, beauty, powers, fountains, caves, rock } \\
\text { shelters and vertical caves). Far fewer managed to provide us } \\
\text { with a well-articulated plot (the marrying of a mortal with a } \\
\text { supernatural being, the midwife who helps the supernatural } \\
\text { being give birth, a mortal who steals the sheets and then } \\
\text { becomes rich). In the "Encantades" group (2IO) there are } 256 \\
\text { entries, of which I37, a very high percentage, can be regarded as } \\
\text { very interesting. }\end{array}$ & 256 \\
\hline 220 & $\begin{array}{l}\text { The Damned } \\
\text { The Damned are those who have been punished eternally, most } \\
\text { of whom because they have not done their duty as humans. The } \\
\text { Bad Hunter is, by far, the best known of the Damned, if only } \\
\text { because there are more tales about him. Ther are also tales about: } \\
\text { El sabater, Pilat, Els balladors, El comte Arnau, L'home de la Lluna, } \\
\text { Fra Gari. To sum up, we have a range of damned characters that } \\
\text { have yet to be forgiven. There are } 223 \text { tales about the Damned } \\
\text { (theme 220) of which Io8 have been rated as very interesting. }\end{array}$ & 223 \\
\hline 230 & $\begin{array}{l}\text { Gnomes } \\
\text { We have archived } 248 \text { tales about gnomes (theme 230), and } \\
\text { in this group } 37 \text { are rated as very interesting and } 58 \text { as rather } \\
\text { interesting. } \\
\text { The gnome is one of our folklore's most interesting fantastical } \\
\text { creatures. For some, it's a mischievous creature; for others, a } \\
\text { malevolent spirit. Some people think of it as a cursed wind or } \\
\text { an invisible beast. Some assure that it is a tiny man and others } \\
\text { a small fire or a wisp. We have also recorded the existence of a } \\
\text { gnome with a name (Llitons or Nitons) and a house (Llitons' } \\
\text { Canyon) near Folgueroles. As you can see, gnomes can take many } \\
\text { forms. If we split Osona into natural areas, there are only little } \\
\text { differences in how gnomes are represented. Generally speaking, } \\
\text { and without going into any great detail, for the people from El } \\
\text { Lluçanès the gnome is a spirit of the wind; for the towns at the } \\
\text { foot of the Montseny it's a will-o'-the-wisp; in Collsacabra and } \\
\text { the Guilleries it is a home spirit and also an incubus. }\end{array}$ & 248 \\
\hline
\end{tabular}




\begin{tabular}{|c|c|c|}
\hline Code & Theme & $\begin{array}{l}\text { Number of } \\
\text { FONOS }\end{array}$ \\
\hline 240 & $\begin{array}{l}\text { Witch } \\
\text { In the chapter on witches (code 240) there are } 694 \text { tales, 8I of } \\
\text { which are rated as very interesting (number 4). Most of them } \\
\text { tell of the characteristics, feats, customs or powers of a person } \\
\text { when they become a witch. Some of these tales portray witches } \\
\text { as old hags, or badly dressed, or solitary, or weird; they must } \\
\text { succumb to evil once a day; they have a pact with the devil; they } \\
\text { know how to brew potions and other magic beverages; they can } \\
\text { transform themselves into birds or foxes; they can put a curse on } \\
\text { you only by looking at you or touching you; they can conjure } \\
\text { up storms and hail; they can cure illnesses and they have other } \\
\text { powers. Also, many other tales tell of witches gathering with } \\
\text { others of their kind to plan mischief; or to plot how to become a } \\
\text { witch; or how to go back to being normal if you no longer wish } \\
\text { to be a witch; or how they were burned at the stake; or how to } \\
\text { get rid of them; or how to recognise them. In other words, it's a } \\
\text { very rich group of legends with a wide array of different plots. }\end{array}$ & 694 \\
\hline 250 & $\begin{array}{l}\text { Apparitions } \\
\text { Most of the tales about apparitions in our archive follow } \\
\text { the classic plot: someone who died comes back to fulfil an } \\
\text { unfulfilled promise. Many of the II2 apparition tales that } \\
\text { follow this plot (code 250) in our archive have a wealth of detail } \\
\text { that enriches their value and increases their rating ( } 54 \text { are rated } \\
\text { as } 3 \text { or 4). Once the word given in life has been honoured, the } \\
\text { apparition vanishes and everyone - the dead and the family - } \\
\text { rests in peace. Usually, the most difficult thing to determine is } \\
\text { exactly what had been promised. }\end{array}$ & II 2 \\
\hline 260 & $\begin{array}{l}\text { Powers } \\
\text { The group entitled Powers (code } 260 \text { ) consists of very different } \\
\text { tales: tales of sorcery and magic; tales in which fear is caused } \\
\text { almost always by supernatural powers (ghosts, strange noises, } \\
\text { screams, visions, etc.); tales in which books are tools for } \\
\text { contacting an unknown power; tales of hidden treasure, tales } \\
\text { in which a priest can exorcise the foul spirits within a mortal's } \\
\text { body or get rid of the pests in a field; tales about healers or other } \\
\text { people who have the power to cure; tales about amulets, gifts } \\
\text { and talismans. } \\
\text { This is the most numerous group of legendary tales (even if } \\
\text { many of them cannot be regarded as legendary tales but are } \\
\text { more like personal beliefs and superstitions than legends). In } \\
\text { this group we have catalogued Io64 entries, of which } 267 \text { have } \\
\text { been rated as a } 3 \text { or } 4 \text {. }\end{array}$ & 1064 \\
\hline
\end{tabular}




\begin{tabular}{|c|c|c|}
\hline Code & Theme & $\begin{array}{c}\text { Number of } \\
\text { FONOS }\end{array}$ \\
\hline 270 & $\begin{array}{l}\text { Beings from Heaven or Hell } \\
\text { Under the title of Beings from Heaven or Hell (code 270) we } \\
\text { have grouped tales about beings from Heaven (angels, saints } \\
\text { and good will), beings from Hell (demons and bad will), beings } \\
\text { from neither Heaven nor Hell (souls and spirits) and beings } \\
\text { from unearthly places (Heaven and Hell). Most of the } 285 \text { tales } \\
\text { archived tell the deeds of Lucifer, Satan, Berrugo, Bitxego or } \\
\text { Birrombau. These are tales of some naivety and even candidness. } \\
\text { The bad side always loses to the good side: good deeds, common } \\
\text { sense, goodwill, Good in general are rewarded; however evil, } \\
\text { bad will, hot-headedness, greed are always punished. The } \\
\text { struggle between good and evil is present in many tales: the } \\
\text { fight between Saint Anthony and the Devil or between the } \\
\text { Devil and an Archangel. Also recurrent in these tales are, on the } \\
\text { one hand, things such as grottos, bridges, goats and pigs and, } \\
\text { on the other, patron saints, wise women, spells, imaginations, } \\
\text { prayers and praying for other people. }\end{array}$ & 285 \\
\hline 280 & $\begin{array}{l}\text { Nature } \\
\text { In the group entitled Nature there are tales about snakes and } \\
\text { other reptiles; the sun and the moon; weather phenomena } \\
\text { and the universe (fog, rain, rainbows, clouds, stars, eclipses, } \\
\text { earthquakes, lightning and thunder, earth, wind, and weather); } \\
\text { animals and plants (lizards, wolves, vipers, cuckoos, roosters, } \\
\text { walnut trees, oak trees, mint, rose, blackberry); human beings } \\
\text { (gypsies, imps, giants, "la mola"); birds, etc Most of the tales in } \\
\text { this group (coded 28o) are told by people who lived intensively } \\
\text { within nature(farmers, shepherds or rangers). These peoplehave } \\
\text { had nature as a part of their everyday lives. The explanations } \\
\text { and descriptions that they give about nature are tangible and } \\
\text { sensitive, based on a rational perception of observed facts. }\end{array}$ & 623 \\
\hline
\end{tabular}




\begin{tabular}{|c|c|c|}
\hline Code & Theme & $\begin{array}{l}\text { Number of } \\
\text { FONOS }\end{array}$ \\
\hline 290 & $\begin{array}{l}\text { About places } \\
\text { The } 579 \text { tales that we have archived in the chapter About places } \\
\text { (code 290) explain something about specific places in Osona, } \\
\text { or beyond. Here we find a legend about a young woman who } \\
\text { jumped off a cliff because she was late for mass, so the place } \\
\text { was known as Salt de la Minyona. And why is Manlleu called } \\
\text { Manlleu, and why does Roda have this evocative name? What } \\
\text { happened at the fountain of the Baroness in Savassona in a } \\
\text { romantic boulevard that leads to a spectacular rock shelter? } \\
\text { Did you know that wounded birds go to Bellmunt to die in the } \\
\text { autumn? Where does the name Salt de la Pujolrassa come from, } \\
\text { in the mountain range of Casadevall near Rupit? The answer to } \\
\text { these questions and many others can be found in the legends in } \\
\text { this group. Notably, more than half of these legends have been } \\
\text { rated as interesting (3oI rated as a 2, } 3 \text { or 4) and the rest as not } \\
\text { very interesting or not at all. }\end{array}$ & 579 \\
\hline $2 \mathrm{Ao}$ & $\begin{array}{l}\text { Bandits } \\
\text { Generally tales about bandits are not very elaborate and have a } \\
\text { plot which is too predictable. Moreover, interesting details are } \\
\text { sparse. For this reason, only Io of the } 354 \text { tales about bandits } \\
\text { (code } 2 \text { Ao) have been catalogued as very interesting (with a } \\
\text { 4) and I50 as of average interest ( } 2 \text { and 3); the rest are of little } \\
\text { interest or unrated. } \\
\text { There are several reasons for this. Osona is a region with a higher } \\
\text { density of bandits than other Catalan regions. The fact that the } \\
\text { area is filled with unpopulated locations, shady places, lonely } \\
\text { houses, isolated churches and many caves apt for use as hideouts } \\
\text { helps a lot. It is also important that, until quite recently, the } \\
\text { region has been isolated from others, hidden away for centuries } \\
\text { between mountains far from the main roads. At the same time, } \\
\text { historically its economic, political, social and religious power } \\
\text { has been recognised by everyone. These characteristics make } \\
\text { the area attractive to bandit life: bandits, deserters or common } \\
\text { thieves. } \\
\text { In this group we have included tales of the "trabucaires" } \\
\text { (blunderbuss wielders), the Carlins (Cabrinetty, Savalls, } \\
\text { Tristany, Huguet), the "sometent" (a paramilitary organisation), } \\
\text { fighters (Bac de Roda) and maquis (Massana). There are also } \\
\text { a good number of thieves' tales (Ferriol, St. Hipòlit, Bac, Bou, } \\
\text { Traveria, Morisco), murderers (Serraller, Vermell), highwaymen } \\
\text { (Cabré, Becaina) and wrong-doers (Gira-rocs, Serra-rica). But } \\
\text { the highlight are the romantic bandits such as the legends of } \\
\text { Perot Rocaguinarda, Serrallonga, Tocasson, Fadrí de Sau, Ramon } \\
\text { Felip and many others. }\end{array}$ & 354 \\
\hline
\end{tabular}




\begin{tabular}{|c|c|c|}
\hline Code & Theme & $\begin{array}{c}\text { Number of } \\
\text { FONOS }\end{array}$ \\
\hline 2Bo & $\begin{array}{l}\text { Children's tales } \\
\text { More than half (227) of all the tales in the group Children's tales } \\
\text { (code } 2 \text { Bo) have been catalogued as interesting. Here we find a } \\
\text { good number of varied tales: El carboner pobre, La muntanya de } \\
\text { vidre, Les tres germanes, La rateta que escombrava l'escaleta, En Pere } \\
\text { sense por, La flor del ponical, La fugida d'Egipte, L'àliga i el rellentí, } \\
\text { El ferrer de Figueres, L'home que va sortir de l'infern, Les nou veritats, } \\
\text { La Ventafocs, El conte de les faves, La Trenca-cametes. The list has } \\
\text { as many as } 4 \text { Ig entries. }\end{array}$ & 4I9 \\
\hline $3 \mathrm{IO}$ & $\begin{array}{l}\text { Remedies } \\
\text { This group is very broad, diverse and comprehensive. We find } \\
\text { explanations of how to cure dermatosis, burns, pneumonia, } \\
\text { hernia, tumours or anginas, and also what to do for a good } \\
\text { birth or how to prepare the balsam of the pup or the unguent of } \\
\text { the snake. We also find prayers, rituals or songs for healing and } \\
\text { superstitions about illnesses. Only one in every seven of them } \\
\text { (39I out of 2829) are rated as interesting. }\end{array}$ & 2829 \\
\hline 4IO & $\begin{array}{l}\text { Prayers } \\
\text { Every thing, action, illness and catastrophe has its prayer. Some } \\
\text { prevent or cure illness, others are humorous, and yet others } \\
\text { honour people, as for help or request luck. Here we can find: La } \\
\text { oració de Sant Marc, Santa Creu; Oració per curar espatllats, Oració } \\
\text { pel mal de ventre, Oració per quan surt el sol, El Pare nostre lo petit, } \\
\text { Oració contra els llamps, Oració per posar-se una camisa, El Déu } \\
\text { m'encoman, Parauleta de Déu, Oració de Sant Antoni. }\end{array}$ & 306 \\
\hline 420 & $\begin{array}{l}\text { Sayings and riddles } \\
\text { Jokes, riddles, set phrases, proverbs, sayings, couplets and } \\
\text { tongue-twisters. }\end{array}$ & I9I \\
\hline 430 & Verses & I43 \\
\hline $5 \mathrm{IO}$ & Festivities & 429 \\
\hline 520 & Games & I89 \\
\hline 530 & Other customs & 632 \\
\hline
\end{tabular}


As well as the research campaigns mentioned above, the GRFO has also done other works on folklore that have enriched the archive. Particularly important are the study by the folklore expert J. M. Vilarmau; the Ist Conference of Folkloric Studies (December I99I); contemporary rumours and legends (a study by the IPEC); folksongs recorded by Verdaguer; the little flute player Roviretes; folksongs about the history of Catalonia; the lyric-narrative song in Guilleries; legends from the Plana de Vic; bandit legends; and a synthesis of the folklore of Osona.

Of all these studies we would like to make particular mention of contemporary rumours and legends. We made a survey of 3758 young people between I5 and I9 years of age. One of the results was that young people are highly knowledgeable of urban legends and they believe them to be highly plausible. The best known were: The Haunted house (44.3\%), the hitchhiker (43.3\%), death on the Dragon Khan (40\%), something hit the roof of the car $(37.2 \%)$, glasses spread with drugs (30.7\%), buried alive $(28.2 \%)$, the grave gamble $(26.5 \%)$.

The plots of these modern tales are not too different from the plots of the old legends. But the way they are told is quite different. Contemporary legends are narrated by the young in a highly schematic fashion, with a wealth of detail but short on rhetoric.

In our romantic spirit, the GRFO has spent more time on research into orally transmitted popular culture (we are specialists in oral folklore) than other aspects of popular culture, such as festivities, dances or "castells". We have decided to catalogue material and folkloric research rather than try to retrieve examples of popular culture.

\section{References}

Grup de Recerca Folklòrica D’Osona (I984): El Folklore de Rupit i Pruit, II. Narracions. L'Entorn. Vic: Eumo.

Grup de Recerca Folklòrica D'Osona; Josep M. PUjol (coord.) (2002): «Benvingut/da al club de la sida» i altres rumors d'actualitat. Temes d'Etnologia 5 . Barcelona: Centre de Promoció de la Cultura Popular i Tradicional Catalana,

Pujol, Josep M. (I985): "Literatura tradicional i etnopoètica: Balanç d'un folklorist”. In Dolors LlopART; Joan PRAT; Llorenç PRATS (eds.): La cultura popular a debat. Barcelona: Fundació Serveis de Cultura Popular / Editorial Alta Fulla, p. I58-I67. [Included in Això era i no era. Obra folklòrica de Josep M. Pujol ed. by Carme OrIOL \& Emili SAMPER. Tarragona: Publicacions URV, 2OI3, p. 25-33] 


\section{Pictures}

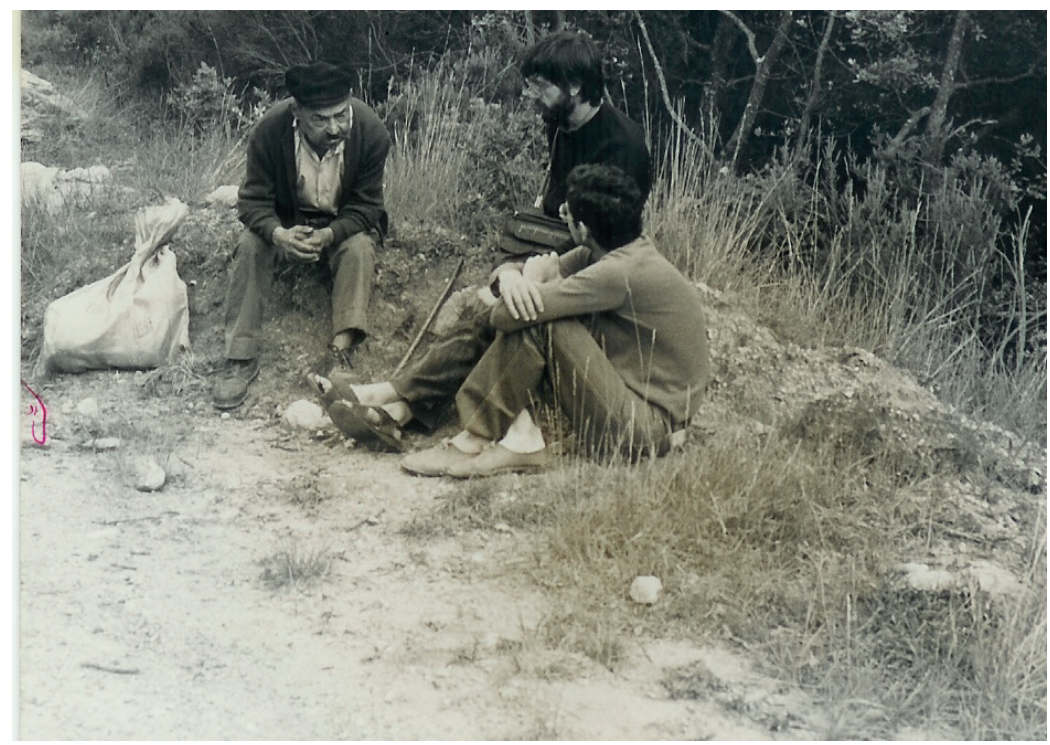

Jaume Ayats and Ignasi Roviró with Josep Crous near Mas Fàbregues (Rupit). July I98I.

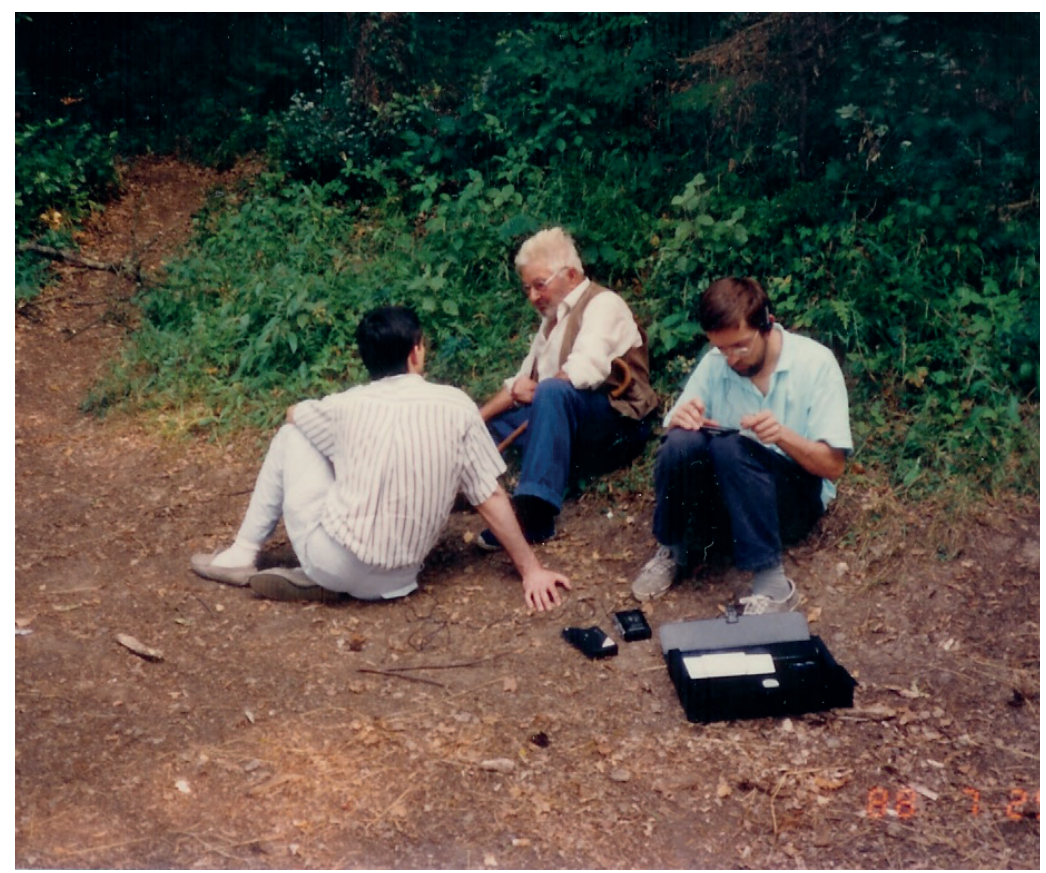

Ignasi and Xavier Roviró with Josep Masnou at the foot of Grioteres (Vilanova de Sau). 29th July I 988. 
The Osona Research Group on Folklore: research and the archive

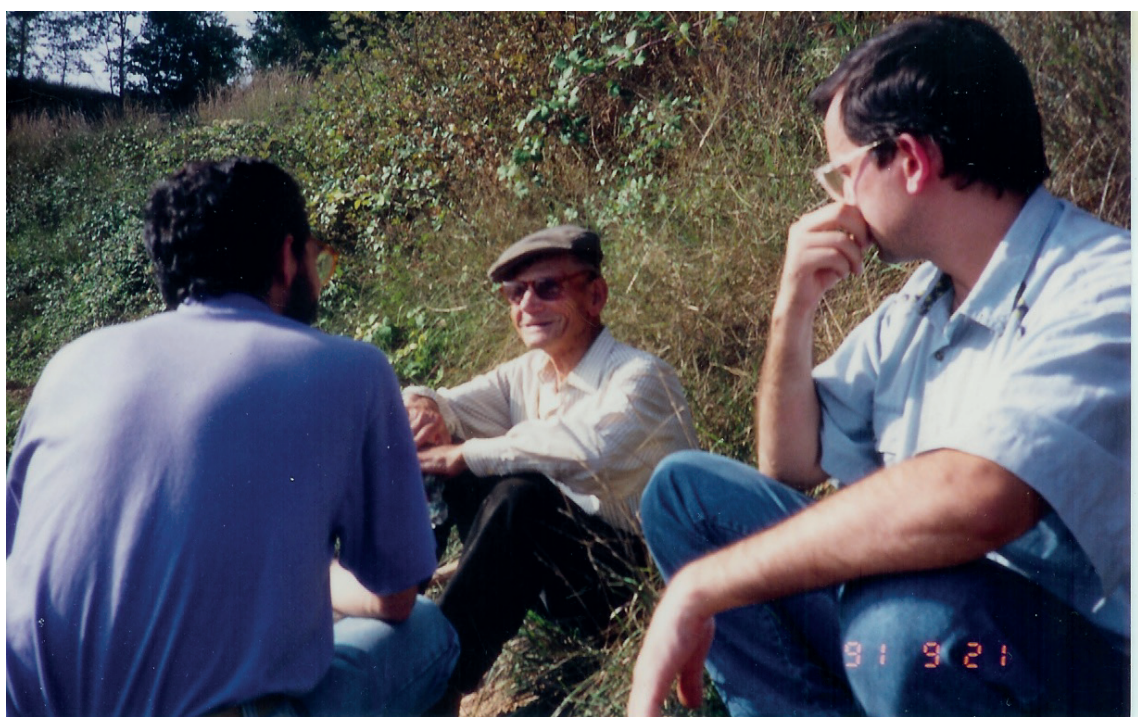

Jaume Ayats and Ignasi Roviró talking with Ramon Compte near Mas Vilabella (Sant Boi de Lluçanès). 2ist September I99I.

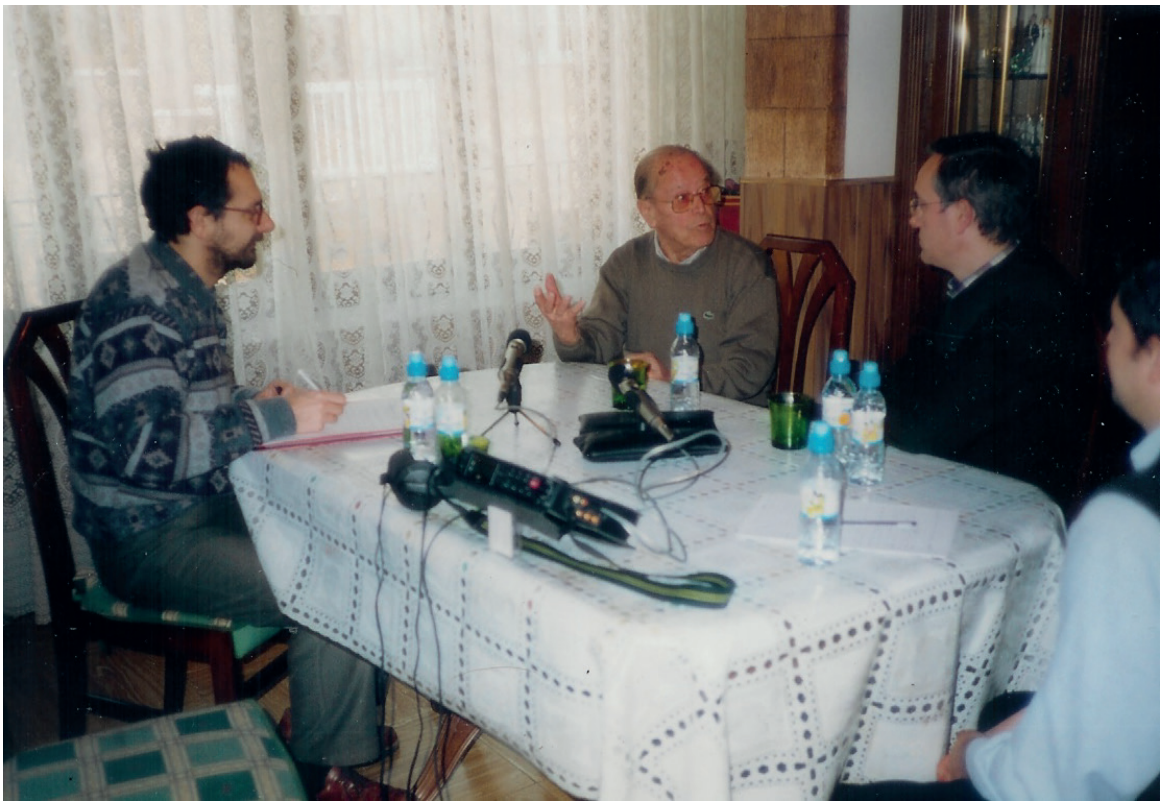

Jaume Ayats and Ignasi Roviró talking with Miquel Sala de Torelló in his dining room. 23rd March 2003. 